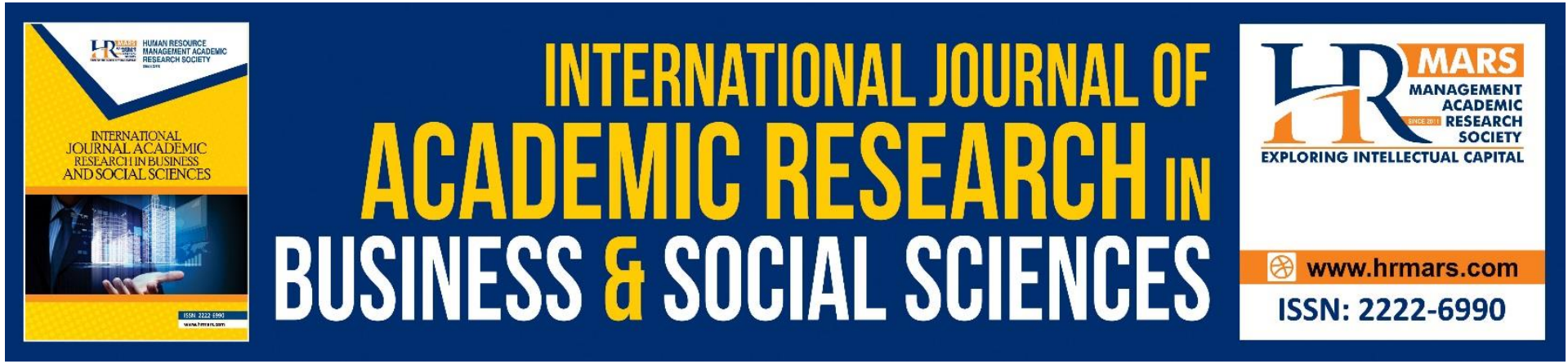

\title{
Distribution of the Congregating Fireflies in Malaysia: A Review
}

\section{Noor Fazeera Ahmad Fuzi, Azimah Abd Rahman \& Faradina Marzukhi}

To Link this Article: http://dx.doi.org/10.6007/IJARBSS/v11-i9/11067 DOI:10.6007/IJARBSS/v11-i9/11067

Received: 16 July 2021, Revised: 07 August 2021, Accepted: 28 August 2021

Published Online: 13 September 2021

In-Text Citation: (Fuzi et al., 2021)

To Cite this Article: Fuzi, N. F. A., Rahman, A. A., \& Marzukhi, F. (2021). Distribution of the Congregating Fireflies in Malaysia: A Review. International Journal of Academic Research in Business and Social Sciences, 11(9), 778-795.

\section{Copyright: (c) 2021 The Author(s)}

Published by Human Resource Management Academic Research Society (www.hrmars.com) This article is published under the Creative Commons Attribution (CC BY 4.0) license. Anyone may reproduce, distribute, translate and create derivative works of this article (for both commercial and non-commercial purposes), subject to full attribution to the original publication and authors. The full terms of this license may be seen at: http://creativecommons.org/licences/by/4.0/legalcode

Vol. 11, No. 9, 2021, Pg. 778 - 795

Full Terms \& Conditions of access and use can be found at http://hrmars.com/index.php/pages/detail/publication-ethics 


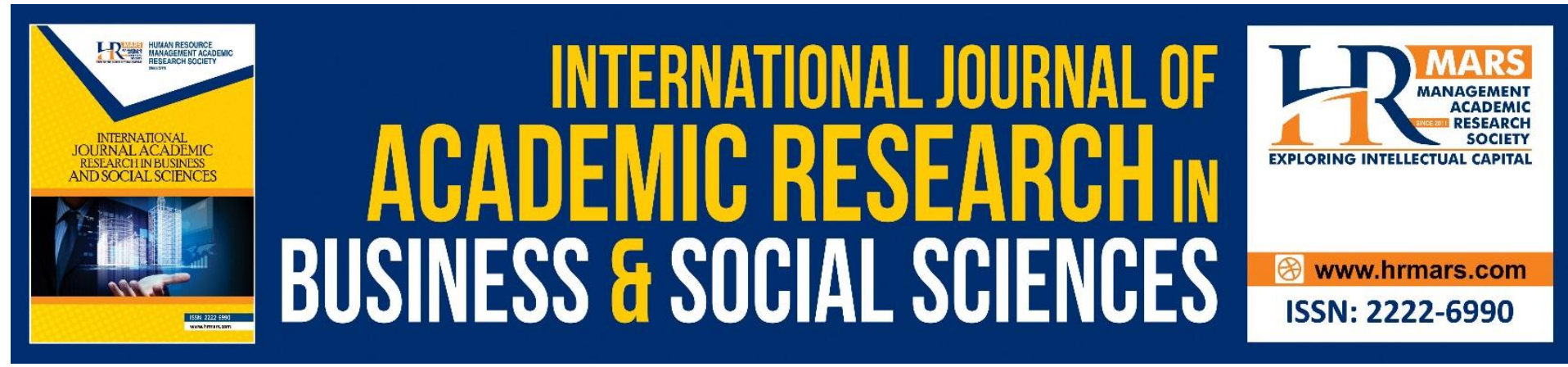

\title{
Distribution of the Congregating Fireflies in Malaysia: A Review
}

\author{
Noor Fazeera Ahmad Fuzi ${ }^{1}$, Azimah Abd Rahman¹ \& Faradina \\ Marzukhi \\ ${ }^{1}$ Geolnformatic Unit, Geography Section, School of Humanities, Universiti Sains Malaysia, \\ 11800 USM, Pulau Pinang, Malaysia, ${ }^{2}$ Faculty of Architecture, Planning and Surveying, UiTM \\ Perlis, 02600 Arau, Perlis
}

\begin{abstract}
Pteroptyx tener is a distinctive bent-winged firefly found in Southeast Asia. This species is an ecotourism attraction in Malaysia because tourists enjoy their synchronous flashing in large numbers on the mangrove trees and shrubs at night. The most known states for firefly studies are Negeri Sembilan, Perak, Terengganu, Sarawak and Sabah in the meantime. This study aims to study the distribution of congregating fireflies in Malaysia. The objectives of the study are to identify the need to sustain the fireflies and their habitat in Malaysia, to describe the characteristics of their habitats and the usage of GIS in preserving and conserving the habitats of firefly. Regarding the potential economic benefits for local communities from firefly ecotourism, for example in Kuala Selangor, Kuala Sepetang and Rembau-Linggi, human activities have started to affect the habitats of the firefly Pteroptyx tener in Malaysia. The general opinion is that, due to habitat loss and degradation anthropogenic sources, firefly populations in these areas have decreased over the years. Five distinct vegetation assemblages comprising different combinations of four species of mangroves were defined. Shorter display sections of $P$. tener colonies had greater percentage coverage. However, the vegetation assemblage which consisting of mainly Sonneratia casseolaris and Nypa fruticans was the most preferred type. Resulting in the necessity to consider not only a single mangrove species but the entire vegetation assemblage for firefly conservation.
\end{abstract}

Keywords: Pteroptyx Tener, Firefly Habitat, Mangrove, Firefly Population, GIS.

\section{Introduction}

Many eco-tourisms agencies are now preferring GIS for the zonation mapping and the analysis for the current moment. Maps are being used to highlight some important area for the zonation studies. GIS is a technology that consists hardware, software, operator and geographical data which helps to store, gather, manipulate and analyze the required information. GIS able to assist where is the highest distribution of fireflies, where is the lowest distribution of fireflies, which parameters depend on the population of fireflies, also helps to analyze the development and environmental changes of vegetations and marine life around the research area. The mapping of zonal analysis on distribution of fireflies helps to find the answers for these questions. 
Firefly or Lampyridae (Pteroptyx tener) belongs to the order Coleoptera, which is the largest order of insects (Mckenna \& Farrell, 2015). It is a distinctive bent-winged firefly found in Southeast Asia which is easily found in hot and temperate climates. This species lives in mangrove swamps or riverbanks areas to be able get their food sources easily. For such a small insect like Lampyridae, it has a big influence on the livelihood of the local people and indirectly to the economy. These unique insects perform their nightly flashing rituals in group of thousands on riverside trees all around Peninsular Malaysia such as Kuala Selangor, Rembau-Linggi, Kuala Sepetang, Kerteh River, while in Sabah there are several locations of congregating fireflies such as Paitan, Tuaran, Sepilok, Pulau Sakar off the coast of Lahad Datu and Kawang River.

Growing Pteroptyx fireflies and reintroducing the species to habitats with low populations is a conservation challenge, with growing pressures from many threats, including firefly tourism and urbanization. Previous studies have shown that Berembang trees plays a dominant role in the selection of habitat for firefly. Berembang trees (Sonneratia caseolaris) is a type of mangrove tree that grows on the shorelines of Peninsular Malaysia (Saib, Dawood, \& Saikim, 2016). The Berembang trees also provide a food supply and a place for breed. Studies of Malaysian firefly colonies at Kuala Sepetang, Kuala Linggi, Sungai Rembau showed that most of fireflies were found at Berembang trees compared to the other type of mangrove trees (Jusoh, Hashim \& Ibrahim, 2010). In the Rembau-Linggi estuary, P. tener has been found congregating on several tree species such as Sonneratia caseolaris and Talipariti tiliaceum growing along a $9 \mathrm{~km}$ stretch of the brackish river (Jusoh \& Hashim, 2012). The riparian area, an interface between land and water, becomes the habitat to a wide range of flora and fauna. Some riparian floras recorded as being found in Malaysia are Sonneratia caseolaris, Hibiscus tiliaceus, Nypa fruticans, Acrotichum aureum, Areca cathechu, Oncosperma tigillarium and Ficus sp. They flash synchronously in order to attract their mating partner for hours after sunset. This species is one of those firefly species that has 'perfect synchronization'.

All of these types of vegetation were commonly found in riparian habitats and are associated with firefly in Peninsular Malaysia and Thailand. Uniquely, one of the riparian vegetation was found to be the most preferable display tree by the synchronous firefly, Pteroptyx tener in Malaysia (Abdullah et al., 2019).

The purpose of this research is to study the distribution of congregating fireflies in Malaysia. The objectives of the study are to identify the need to sustain the fireflies and their habitat in Malaysia, to describe the characteristics of their habitats and the usage of GIS in preserving and conserving the habitats of firefly.

\section{Literature Review}

Abdullah et al. studied that the riparian area, an interface between land and water, becomes the habitat to a wide range of flora and fauna. The riparian vegetation apparently supports both aquatic and terrestrial insects. Firefly is a huge commodity for this country as it becomes a center of attraction in the ecotourism industry. The flashing light of firefly is captivating for the tourist visiting the riparian zone as its natural habitat. It is advantageous to have knowledge of other insect populations living in the same riparian zones as an effort for firefly conservation, as well as the entire riparian ecosystem. This study is a preliminary assessment done to identify the insect community in the riparian zone, identify the vegetation in which the Insect community resides and determine changes in insect community across several environmental parameters (salinity, wind speed, temperature and humidity). 
Juliana et al. explains that Fireflies mainly preferred $S$. caseolaris as their main display tree. Streambank palms such as Nypa fruticans and $M$. sago are important as food sources for the snail preys that the firefly larvae feed upon. The firefly larval density was reported to be higher in the Sago palms groves than the oil palm stands. Most of the natural vegetation along the riverbanks of Selangor River had been disturbed and this can be confirmed by the low density and distribution of the riparian plants favored by the fireflies. More intensified and structured conservation and replanting programs involving the Berembang trees can ensure the survival of fireflies in this unique habitat for ecotourism sustainability of the Sepetang estuary, Perak. According to Jusoff \& Taha (2009), knowledge or data on mangrove destruction is minimal. Being a delicate ecosystem, due to slight changes in the natural climate, mangroves appear to fluctuate. In response to the growing demand for urban and infrastructure growth, beach resorts and aquaculture ponds, rapid development has led to the clearing of mangrove regions. Industries and factories near rivers and streams could emit their wastes into the water systems, polluting the river systems area and crippling it (Jusoff \& Taha, 2009). Their natural balance may be affected by critical genetic diversity required for medical and agricultural purposes, disrupting their ability to protect the coastline.

Khoo et al (2008) stated there are a few places in Malaysia that carry out firefly watching tours along the river (that is Sungai Sepetang and Sungai Kerian in Perak, Sungai Chukai and Sungai Setiu in Terengganu, Cherating in Pahang) which will most likely have some issues with artificial light sources from nearby townships and villages. In addition, as the neighboring areas have several aquaculture ponds that use spotlights during the night, Sungai Sepetang is facing another challenge. The light source usually comes in yellow and white colors from spotlights, floodlights, streetlights, and households. Studies have investigated the influence of various colored light sources on the flashing fireflies will be important.

Jusoh et al (2010) explained more than one element might be at mind when it comes to the relationship between firefly population and vegetation compositions. To begin with, although fireflies do not mate on their wings, they use trees as a mating spot (Buck and Buck, 1966). Researchers believe that there are five variables that determine the decision to install a display tree: 1 . The display tree should be at the riverbank, as this encourages fireflies to communicate more easily. 2. Each display tree's leaf structure must be appropriate for mating purposes. 3. The display tree must have nectarines or sap when adult fireflies feed it, 4 . The display tree must be near a larval prey food plant, and 5 . The display tree must be in good health.

However, Jusoh \& Hashim (2012) found that over the span of two decades, the Rembau River's mangrove forest had been extensively transformed and shifted to new land uses. All of these encroached on the buffer zones established by DID guidelines. Since the firefly's original habitat is destroyed and disrupted, the change of wetlands to agriculture is bound to endanger the population. Researchers anticipate that unless immediate and serious actions are implemented to conserve the firefly, the number will steadily decline and eventually extinct. To assist preserve the sustainability of the firefly population, it is suggested that remaining habitat to be maintained and the number of fireflies monitored.

Lin (2000) depicts a myriad of valuable information can be extracted from primary data using GIS technology. Decision makers may execute required investigations on locations where both the appeals and public views refer before modifying zoning maps. Landowner appeals, public hearings, committee recommendations, and site investigations are all examples of GISbased information flow. 
Kardavani (2013) combined HEC-RAS model for zoning. The maps were made with AutoCAD, then AutoLand software was used to overlay elevation points around and even inside the river. Thousands of sections may be retrieved using the tool for generating surface features, but this is time consuming, therefore just a few parts were chosen. The data was loaded into ARCGIS and flood zones were visually drawn after completing all of the aforementioned stages in HECRAS. Researchers discovered that when the number of return periods increases, the water level rises.

Soysal (2012) revealed method to improve the performance obtained by ArcGIS' zonal statistics. The proposed normalization phase is utilized in hot-spot analysis to identify patterns and/or trends in crashes. Within the same scale, the method makes it possible to compare statistical parameters across various zone areas. This aids decision-makers in identifying areas with a higher crash index and taking preventative actions.

Zhang (2015) briefed the level of vulnerability of urban areas using GIS zoning approach which it is measured by urban ecological vulnerability. According to its vulnerabilities, the city may be categorized into five categories: very low, low, medium, high, and very high. There are three different types of regulatory zones: ecological green line, ecological grey line, and ecological red line. The grey line region can serve a variety of purposes in the city's development strategy. It gives evidence for urban ecological conservation and sustainable development decision-making.

Chunye (2017) portrayed China has developed marine spatial planning as a valuable management tool for allocating marine uses and conserving marine resources for decades. Sector-based marine function zoning (MFZ) becomes insufficient for addressing the complex and conflicting uses of marine and coastal regions as the number and intensity of industrial applications grows. As a result of this issue, regulations for marine environmental protection based on the Ecological Red Line (ERL) concept have been developed.

Saaty (1971) developed the Analytic Hierarchy Process (AHP) which it is a broad measuring theory. Scales may be derived from both discrete and continuous paired comparisons using this method. Actual measurements or a basic scale that indicates the relative strength of preferences and sentiments can be used to make these comparisons. The AHP is particularly concerned about deviations from consistency, measurement, and dependencies within and across groupings of elements in its structure. By breaking intricate decisions into pairwise comparisons of two at a time, Saaty (1988) created a structured method for assessing them. The analytic hierarchy process (AHP) entails breaking down large and intangible decision issues into little sub-problems that may be compared pair-wise. Comparative weights for the different criterion layers were calculated using an AHP plugin tool for the ArcGIS environment. It generates the consistency ratio (CR), which is a metric for logical contradiction between expert and user judgements during expert judgement. The need for a good CR measurement helps in the detection of possible mistakes, and therefore judgement improvement is relying on $\mathrm{CR}$ as in Eq. (1).

$$
C R=\frac{C I}{R I}
$$

Where, $\mathrm{Cl}$ represents Consistency Index and RI represents Random Index. Saaty (1988) provided a 'fundamental' scale for computing pair-wise comparison matrix of the criteria layers while performing an AHP. This involves a construction of a matrix where each criterion is compared with the other criteria, relative to its importance, on a scale from 1 to 9 . Scale 1 indicates equal preference between a pair of criteria layers whereas 9 indicates a particular criteria layer is extremely favored over the other. If the CR value is much in excess of 0.1 , the judgments are untrustworthy because they are too close for randomness. 
Mishra (2015) simplified AHP is used to set up the structure by determining the weightage of particular requirement in the entire decision-making process for a collection of criteria, subcriteria. As its weights represent the proportional relevance of each criterion, they must be carefully chosen. AHP may be used to conduct pairwise comparisons between criteria, which simplifies the process. By selecting the eigenvector corresponding to the matrix's greatest eigenvalue and standardizing the total of the components to unity, it determines the weighting for each criterion. In other words, AHP is one of the promising methods used for the agricultural land suitability analysis based on individual criterions through quantitative analysis. GIS technology is used to formulate different criteria maps which are used in AHP to construct the site suitability model for organic farming. Integration of GIS with multi criteria evaluation methods reveals its extreme applicability in site suitable analysis.

Chandio et al. (2013) claimed the previous research used a GIS-based AHP as a multi-criteria evaluation technique. The major benefit of this approach is that it may be completed rapidly by integrating data processing and GIS capabilities into the land use decision-making process. The findings of this study will be beneficial in future land-use and development planning.

\section{Methodology}

This study retrieved a systematic literature review; journal articles were acquired from the two major online databases, such as Elsevier (Science Direct) and Google Scholar. The literature review includes both revies and empirical research from prominent publications, most of which were indexed by SCOPUS and some by Web of Science.

The PRISMA approach (refer Figure 1) was used to carefully and systematically identify relevant research from the pool of literature prior to the in-depth review procedure. Identification, screening and inclusion are all covered by this method's four-phase flow diagram. Computerized searches were conducted using keywords such as firefly in Malaysia, Zonation of firefly, GIS Zonation, AHP. Following then, for the Identification phase began with the year of the search and lasted ten (10) years, from 2010 to 2020. Although this intends to emphasize the most current findings on the issues, the year covered is quite recent.

All entries such as papers were found in the Elsevier database were 1,999 papers, whereas Google Scholar identified 1,001. Based on these two databases, a total of 3,000 papers were found. Next, all duplicate articles were carefully reviewed and eliminated. This screening is required to avoid duplicated articles out of the review process. As a result, 58 papers were kept after the duplicates were removed. On the basis of these 58 publications, a screening procedure based on titles and abstracts was conducted to determine the suitability and relevancy of the articles. The variables used to assess the suitability and validity of the articles were based on the study's objectives, which emphasized on zonation of firefly, firefly or Lampyridae Population, zonation in GIS and AHP \& GIS. These keywords are also important in determining the population of firefly in Malaysia, and the useful of GIS in preserving the habitat of firefly. Upon screening, 28 articles were eliminated, bringing the total number of papers in the next phase to 30 .

The articles were then further examined based on their complete step and contents for the third step on their eligibility of the screened articles, in other words full-text articles accessed for eligibility. The total number of papers was reduced to 14 after this procedure, which determined if the articles were genuinely eligible based on the established criteria and condition such as population of firefly using GIS approach and the distribution of firefly at scattered locations. As a result, only 14 final articles were included for reviewing purposes throughout the inclusion phase, spanning the years 2010 to 2020 where the year covered 
changes from the identification phase since some articles were not suitable and related to the topics and aims following the screening and inclusion process. Finally, an in-depth review was conducted to solve the research objectives.

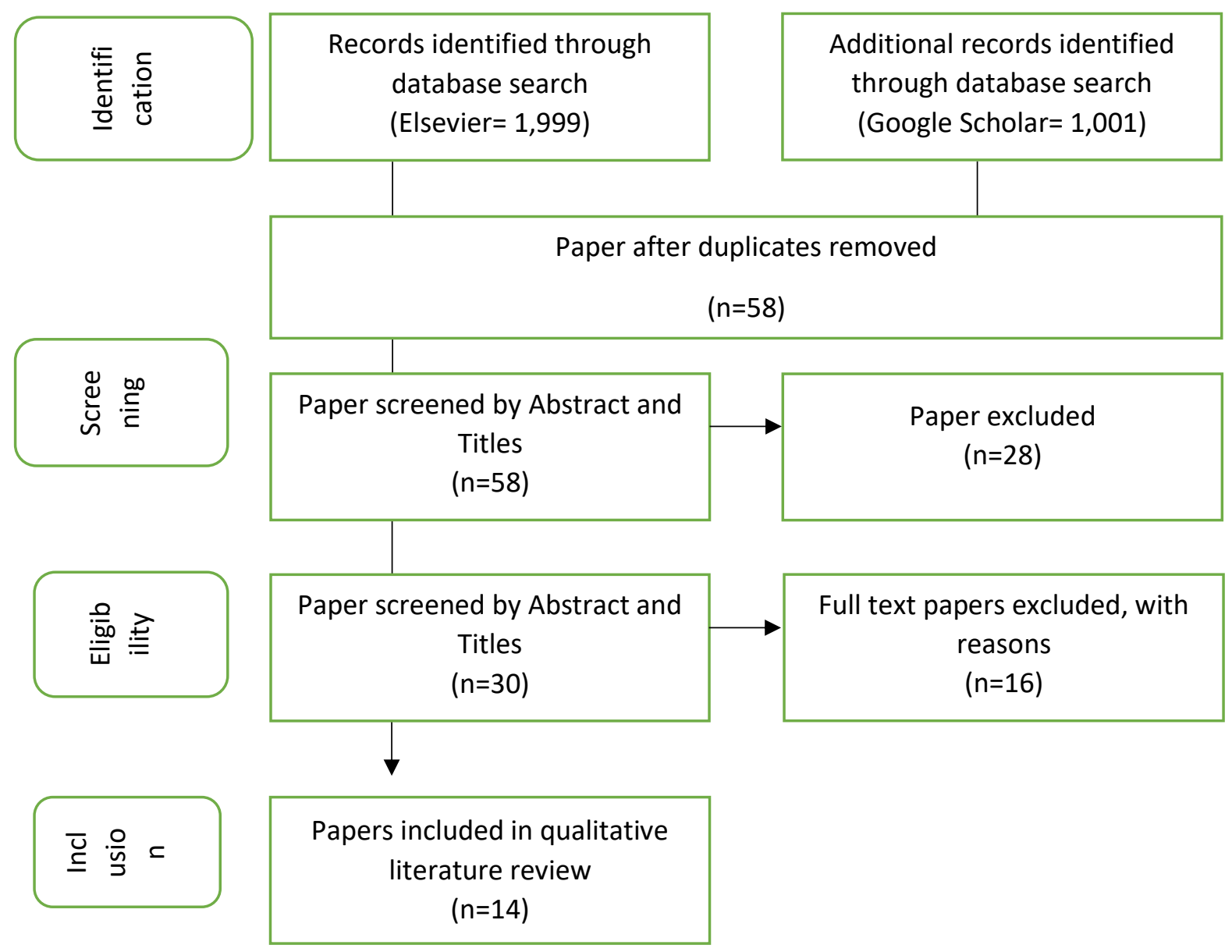

Figure 1. A PRISMA Methodology Flowchart

Source: UNC Health Science Library (2021). Creating a PRISMA flow diagram. Retrieved from http://pubmed.ncbi.nlm.nih.gov/19631507/

\section{Research on Congregating Firefly in Malaysia 2010-2020}

Although, as indicated in Table 1, prior research has been used various terminology for firefly distribution such as firefly congregating, firefly population. However, GIS approaches have been used to facilitate the data collection and listed out the presence zone of firefly along with their preferred habitats.

Table 1. Previous studies on Congregating Firefly in Malaysia 2010-2020

\begin{tabular}{|c|c|c|c|c|c|}
\hline No & Author & Year & Field of Study & Location & Research Concern \\
\hline 1 & Jusoh et al. & 2010 & GIS & $\begin{array}{l}\text { Kg Dew, Kuala } \\
\text { Sepetang, } \\
\text { Perak. }\end{array}$ & $\begin{array}{l}\text { Investigating the relationship } \\
\text { between firefly distribution } \\
\text { and abundance of mangrove } \\
\text { vegetation assemblages. }\end{array}$ \\
\hline
\end{tabular}


INTERNATIONAL JOURNAL OF ACADEMIC RESEARCH IN BUSINESS AND SOCIAL SCIENCES

Vol. 11, No. 9, 2021, E-ISSN: 2222-6990 (c) 2021 HRMARS

\begin{tabular}{|c|c|c|c|c|c|}
\hline 2 & Jusoh et al. & 2011 & GIS & $\begin{array}{l}\text { Sungai Kerteh, } \\
\text { Terengganu }\end{array}$ & $\begin{array}{c}\text { Zonation of fireflies } \\
\text { congregating at their } \\
\text { dominant habitats along } \\
\text { Kerteh River }\end{array}$ \\
\hline 3 & Juliana et al. & 2012 & GIS & $\begin{array}{l}\text { Kg Kuantan, } \\
\text { Kuala Selangor }\end{array}$ & $\begin{array}{l}\text { Vegetation profile of firefly } \\
\text { habitat along riparian zones } \\
\text { to indicate the ecological } \\
\text { relationship between display } \\
\text { tree and firefly. }\end{array}$ \\
\hline 4 & Nada et al. & 2012 & $\begin{array}{c}\text { Forest } \\
\text { Biodiversity }\end{array}$ & Selangor River & $\begin{array}{l}\text { Monitoring the firefly } \\
\text { population to quantify the } \\
\text { firefly aggregation on tree. }\end{array}$ \\
\hline 5 & Jusoh et al. & 2012 & $\begin{array}{l}\text { Environmental } \\
\text { Science }\end{array}$ & Malaysia & $\begin{array}{c}\text { Specific location with } \\
\text { coordinate on distribution of } \\
\text { the synchronous Pteroptyx } \\
\text { tener }\end{array}$ \\
\hline 6 & $\begin{array}{l}\text { Jusoh \& } \\
\text { Hashim N.R. }\end{array}$ & 2012 & $\begin{array}{l}\text { Environmental } \\
\text { Science }\end{array}$ & Rembau-Linggi & $\begin{array}{c}\text { Effect of habitat modification } \\
\text { on firefly population using } \\
\text { GIS buffer zones. }\end{array}$ \\
\hline 7 & $\begin{array}{l}\text { Dawood \& } \\
\text { Saikim }\end{array}$ & 2013 & $\begin{array}{l}\text { Tropical } \\
\text { Biology and } \\
\text { Conservation }\end{array}$ & Sabah, Malaysia & $\begin{array}{c}\text { A review on congregating } \\
\text { fireflies (Pteroptyx sp.) in } \\
\text { Sabah, Malaysia. }\end{array}$ \\
\hline 8 & $\begin{array}{l}\text { Khoo, V. \& } \\
\text { Nada, B. }\end{array}$ & 2014 & GIS & $\begin{array}{c}\text { Sepetang River, } \\
\text { Perak }\end{array}$ & $\begin{array}{l}\text { To ensure the livelihood of } \\
\text { the local people in the area } \\
\text { via firefly ecotourism is } \\
\text { sustainable. }\end{array}$ \\
\hline 9 & $\begin{array}{l}\text { Kevin F. \& } \\
\text { Dawood. }\end{array}$ & 2015 & $\begin{array}{l}\text { Tropical } \\
\text { Biology and } \\
\text { Conservation }\end{array}$ & $\begin{array}{c}\text { Sungai Teratak, } \\
\text { Sabah }\end{array}$ & $\begin{array}{l}\text { A healthier display tree } \\
\text { favors more insect diversity } \\
\text { might have resulted in a } \\
\text { beneficial relationship } \\
\text { between firefly and other } \\
\text { insect populations. }\end{array}$ \\
\hline 10 & $\begin{array}{c}\text { A. Shahara, et } \\
\text { al. }\end{array}$ & 2017 & Ecosystem & $\begin{array}{l}\text { Sg Bernam, } \\
\text { Selangor }\end{array}$ & $\begin{array}{l}\text { Assessment of new } \\
\text { ecotourism site of abundance } \\
\text { fireflies. }\end{array}$ \\
\hline 11 & $\begin{array}{l}\text { I.R. Hazmi \& } \\
\text { S.S.S Aliya }\end{array}$ & 2017 & $\begin{array}{l}\text { Centre for } \\
\text { Insects } \\
\text { Community }\end{array}$ & $\begin{array}{c}\text { Sungai } \\
\text { Sepetang, Kg } \\
\text { Dew, Perak }\end{array}$ & $\begin{array}{l}\text { Investigating the correlation } \\
\text { of water and soil quality to } \\
\text { the abundance of firefly } \\
\text { along the stream. }\end{array}$ \\
\hline
\end{tabular}


INTERNATIONAL JOURNAL OF ACADEMIC RESEARCH IN BUSINESS AND SOCIAL SCIENCES

Vol. 11, No. 9, 2021, E-ISSN: 2222-6990 ㄷ 2021 HRMARS

12

$\begin{array}{ccc}\text { Salleh et al. } 2019 \quad \begin{array}{c}\text { Environmental } \\ \text { Science }\end{array} & \begin{array}{c}\text { Kg Kuantan, } \\ \text { Selangor }\end{array} & \begin{array}{c}\text { The ultrastructure of the light } \\ \text { organ of fireflies, Pteroptyx } \\ \text { tener. }\end{array}\end{array}$

13

Sg Sepetang, Sg

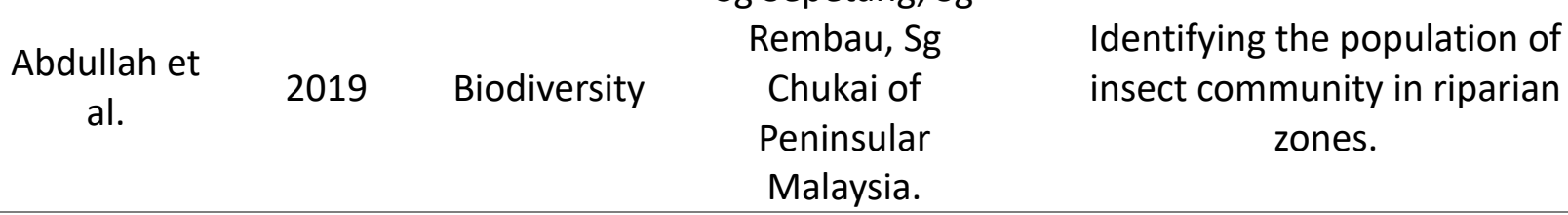

14

$\begin{aligned} & \text { Abdullah et } \\ & \text { al. }\end{aligned}$
$2020 \quad$ Biodiversity Miri, Sarawak

Abiotic Factors influencing

distribution of congregating fireflies.

Khoo \& Nada (2014) discussed Sonneratia caseolaris and Nypa fruticans dominate the firefly habitat in Sepetang River, with a mix of Rhizophora spp. stands. Rhizophora spp. regions are occasionally flooded by river water. Human activities such as fishing jetty, charcoal factory, prawn farming, and oil palm plantations can be seen along the river. Shaded, wet, and organically rich environments are required for the larvae and snails. Aside from habitat needs, oil palm farms may require pesticide treatment, which might endanger the firefly population's survival. It is advised that the "Firefly Forest Reserve" to have a buffer zone of at least 50 metres on both sides of the riverbank. The buffer zone region should be altered as little as possible and should preferably consist of natural riverine vegetation. These buffer zones are essential for preserving firefly breeding areas while also limiting riverbank erosion.

During new moon nights, Shahara et. al (2017) concluded the percentage cover estimation of fireflies was greater than during full moon nights. During full moon nights, there were brighter sources of light, and the fireflies may have been light sensitive and disoriented by the bright moonlight. This might explain why they're more common on nights when the moon isn't shining brightly or when light sources are limited. However, it is concluded the male fireflies were more plentiful than the females with a male-to-female ratio of 3:1.

The distribution of P. tener along Kerteh River as in Figure 2 is concentrated along the part of the river where the dominant vegetation species is $S$. caseolaris using zonal analysis to facilitate the specific location of the congregating fireflies. The fireflies were found in different mangrove assemblages, which is consistent with previous studies (Jusoh et al., 2011). Pteroptyx species were divided into three zones along the river. The dominant species was $P$. tener along a distance of about six $\mathrm{km}$. The vegetation along this zone is less tolerant to salt. In the third zone of about five km, only $P$. bearni was found. This zone was vegetated by true mangrove species such as X. granatum, R. Apiculata, A. Alba and E. Agallocha. Other display trees in this zone were $H$. Tiliaceus and $B$. Argentata, which is categorized as deficient species. 


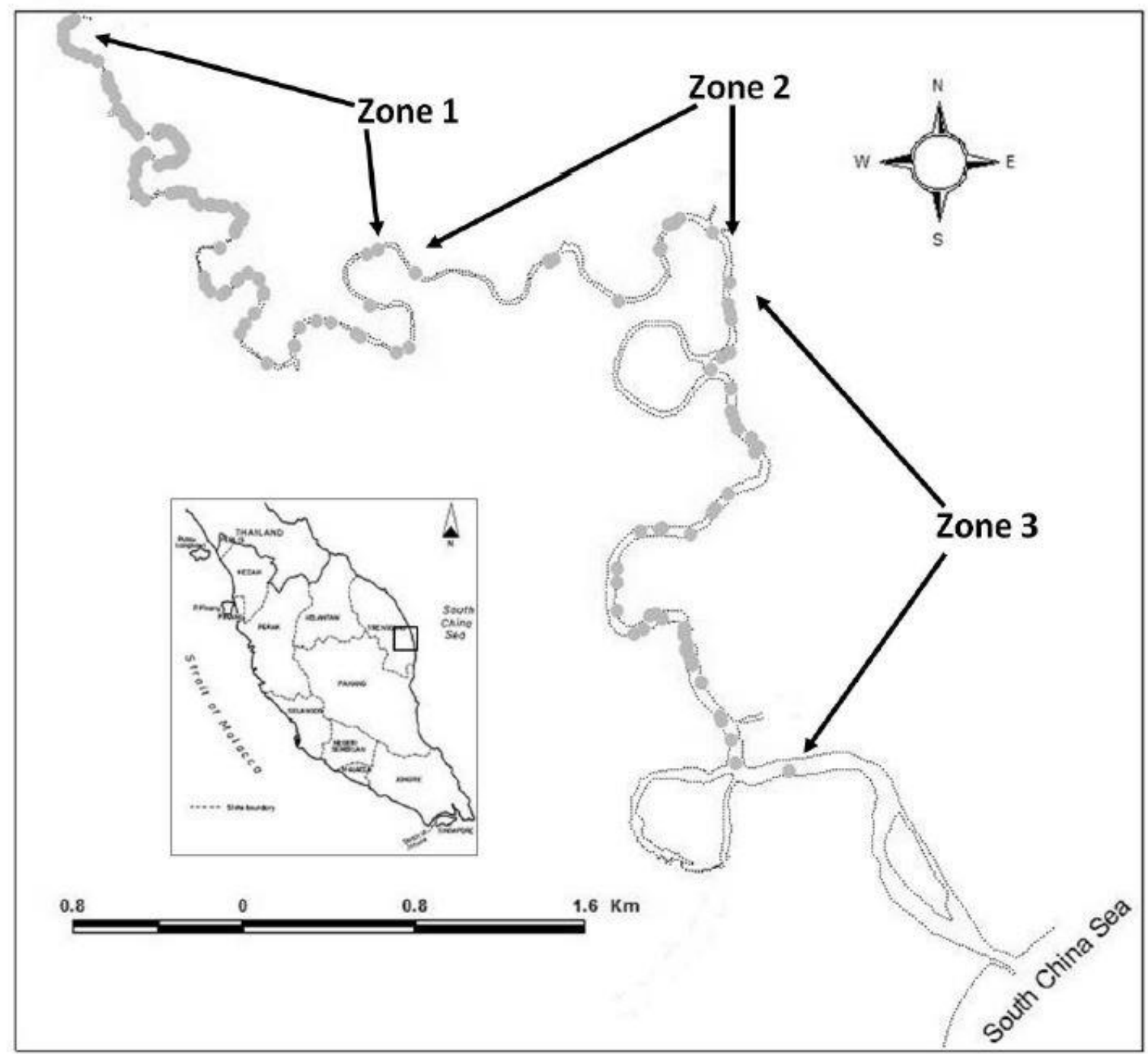

Figure 2. Zonation of Firefly in Kerteh River (Jusoh et al, 2010)

The distribution length of $P$. tener along the Sepetang River was measured to be about $8 \mathrm{~km}$. In all 20 display sections, the fireflies display their light on a single mangrove species using GIS approaches such as zonal analysis. The Spearman test in (Jusoh et al., 2010) showed that the shorter the length of display section, the higher the percentage cover on $P$. Tener colonies. The average percentage cover in this Sepetang estuary was $5 \%$. In total, we could classify five vegetation assemblages associated with the abundance of P.Tener in this estuary. The relationship between firefly abundance and vegetation assemblages could be attributed to more than one factor. Since the fireflies do not mate on the wings, they use trees as the congregation site for mating. For a tree to be selected as a display tree, there are five factors influencing the selection of display trees; 1) fireflies need a display tree at the edge of the water because it facilitates communication; 2) each display tree's leaf arrangement must be ideal for mating; 3 ) if adult fireflies eat, the nectarines or sap must be available on the display tree; 4) the display tree must be near to larval prey food plant and; 5) must be in healthy condition. 


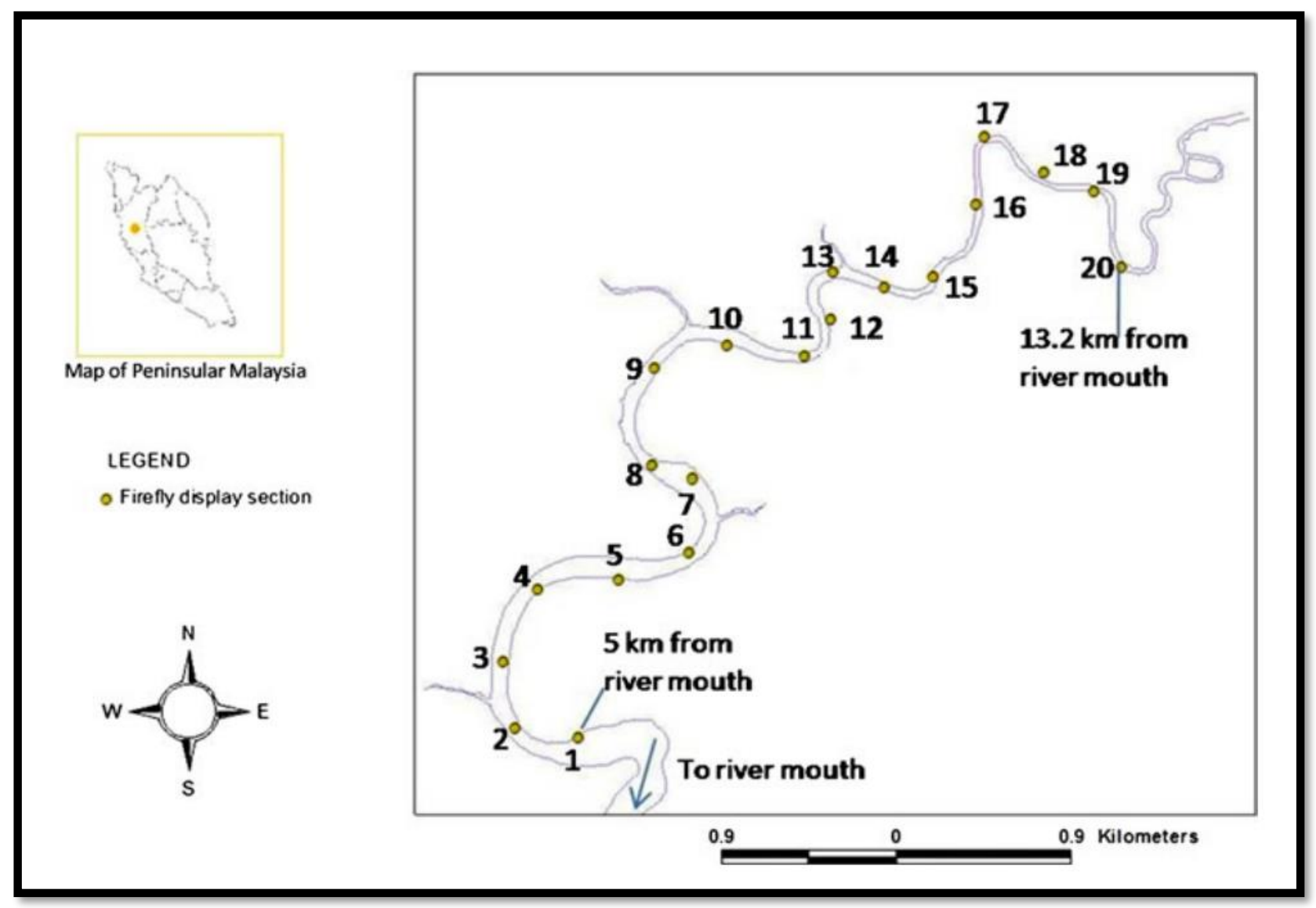

Figure 3. Location of Sampling Points at Kuala Sepetang River, Perak. (Jusoh et al., 2010)

The presence of firefly and their display trees is mostly mentioned in published research in East Malaysia. However, the majority of comprehensive published firefly research in Malaysia were conducted in West Malaysia. Other areas, such as north and east Sabah, require further attention. The distinctive congregating fireflies, as well as the intertidal mangrove estuaries, need to be protected and conserved immediately. Figure 3 portrayed the congregating firefly zones in Sabah which consists along 15 zones starting from Sipitang River to Likas River until Kinabatangan River until Semporna-Pegagau-Tawau River. According to Figure 3, the distinguished zones were: 1- Sipitang River (s), (n); 2- Padas River-Weston Nature Park; 3Klias-Binsulok-Garama Rivers (s), (n); 4- Likas River (s); 5- Likas Wetland (s); 6- Kinarut-Kawang Rivers, (s); 7- Mengkabong River, Tuaran (s),(n); 8- Kampung Sabandar, Tuaran (s), (n); 9Kudat Bay (s); 10- Paitan River (s), (n); 11- Sugut River, Sabang Estate; 12- Sepilok Kecil River (s),(n); 13- Kinabatangan River, Danau Pitas (s); 14- Pulau Sakar, Lahad Datu (s), (n); 15Semporna River-Pegagau-Tawau area $(s),(n) ;(S)=$ synchronous fireflies; $(n)=$ nonsynchronous fireflies.

The research of fireflies is becoming a topic of interest since this insect has the potential to become a product for nature tourism in Sabah. Their capacity to produce coordinated, rhythmic flashing lights in massive crowds has made them popular. Furthermore, the loss of their natural habitat, mangrove forests, has resulted in their extinction in several areas, necessitating further research. The Pteroptyx genus of fireflies has the potential to be used as a nature tourist attraction. This genus is distinguished by vast congregations and synchronized flashing. Currently, there are a few locations in Sabah where we may witness enormous populations of fireflies flashing, with some even displaying mass synchronization (especially 
P. tener, and some said P. Malaccae, but not other species in the genus). Almost all other natural habitats, such as those in the Likas region, have been destroyed away with the rest of economic development. Due to anthropogenic disruptions, the mangroves in Likas are no longer suitable for sustaining firefly populations. These disruptions not only bring pollutants to mangrove regions, but also artificial light, which disrupts firefly light communication and finally leads to their extinction.

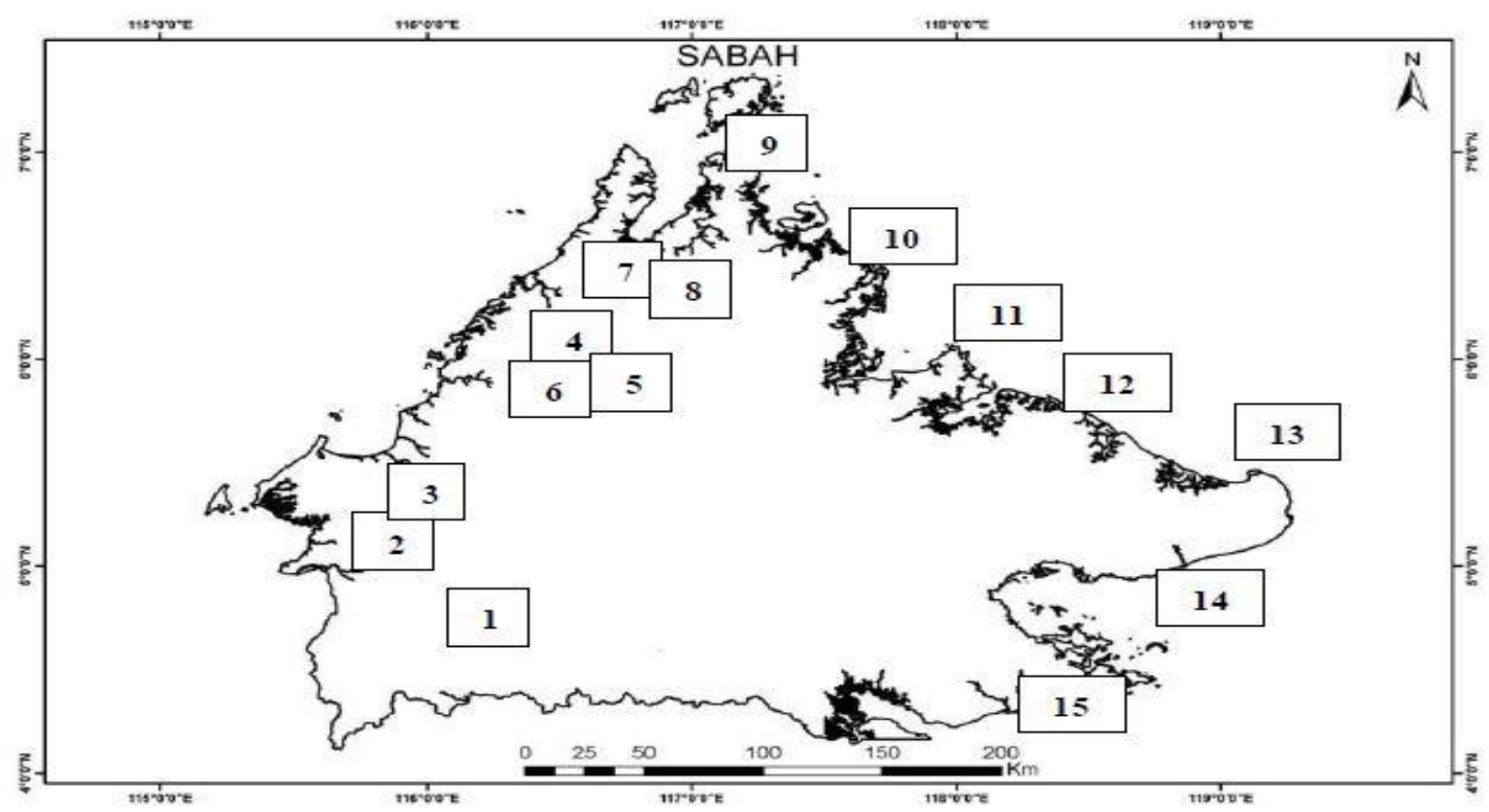

Figure 4. Congregating firefly zones in Sabah. (Dawood \& Saikim, 2016)

In Sarawak, a study has been carried out in three different sampling stations (Figure 4), there were three rivers in Miri; Sungai Raan, Sungai Niah and Sungai Sibuti have been reported by locals as having synchronous firefly congregations (Abdullah et al., 2021). P. bearni was discovered in all of Miri's research areas, including Sungai Niah, Sungai Sibuti, and Sungai Raan. Pteroptyx tener has also been seen at Sungai Kerteh, Terengganu, on Peninsular Malaysia's East Coast (Jusoh et al., 2011). The lowest firefly abundance was found in Sungai Raan, which is most likely attributable to the river's location in the heart of a fishing village. The firefly gazing activity, on the other hand, has great aesthetic value and socioeconomic potential and may be assisted while cruising the river through the fishing villages. The firefly display trees in Miri, Sarawak, were discovered to be differ from those in Peninsular Malaysia. Sonneratia caseolaris is the preferred tree for P. tener to cluster on in Malaysia. P. bearni, on the other hand, would cluster mostly on the two main mangrove species, R. apiculata and B. parviflora, in Miri. According to the findings, a range of different plant species might be used as host/display trees for the firefly. GIS Approach in the study is the buffer and extraction where the sampling sites have been extracted from the Google Maps to locate the study areas as whole. Thus, it made the study easier with decision-making for the sampling sites. 


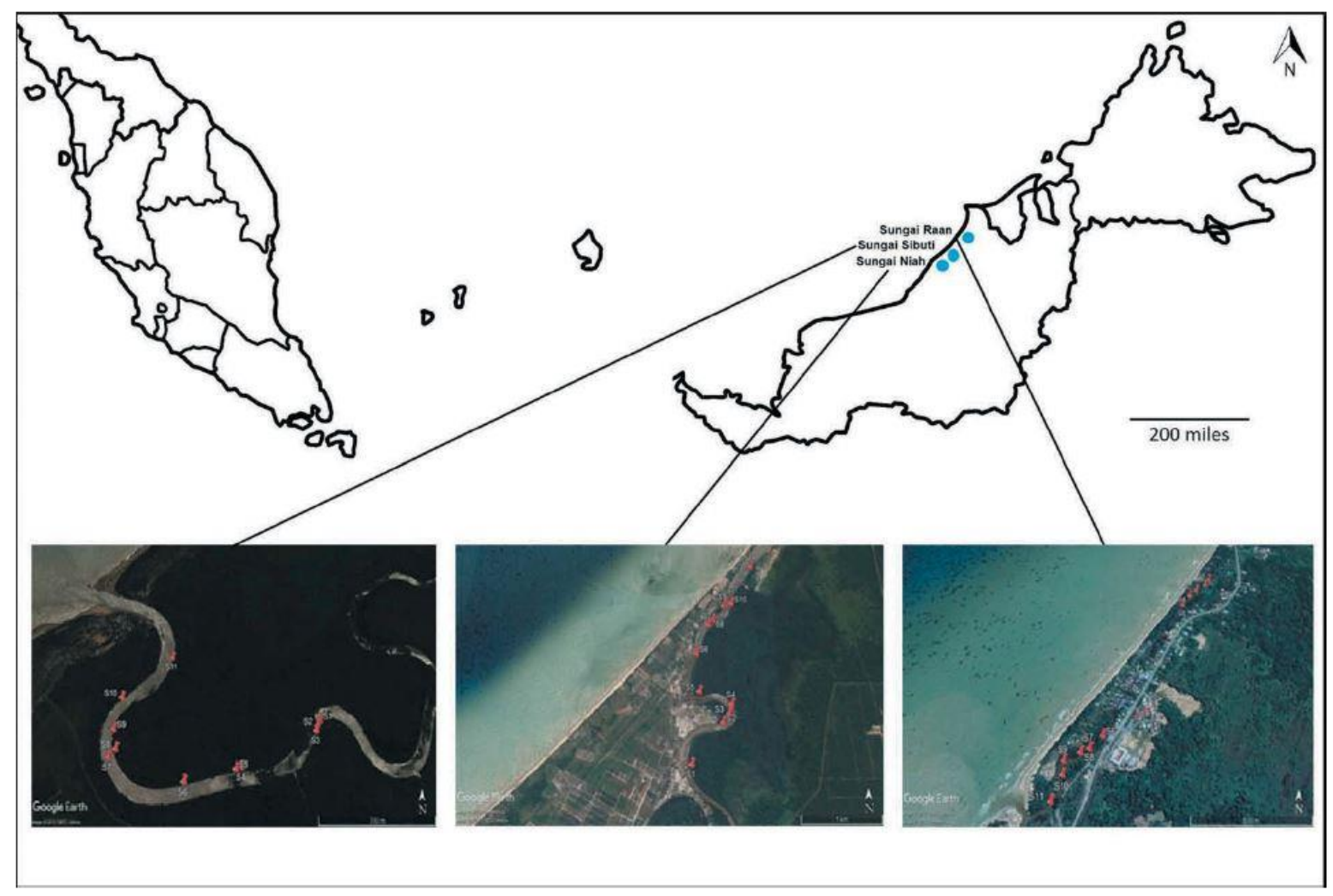

Figure 5. Three Sampling Stations in Miri, Sungai Raan, Sungai Niah, Sungai Sibuti.

(Abdullah et al., 2021)

The mangrove forest along Malaysia's Rembau River has been extensively converted to other land uses such as agriculture, aquaculture and urban areas. The degazetting of the mangroves as a forest reserve in 2004 was a key factor in the extensive invasion where the invasion was led to the planting of oil palm and rubber in riparian areas as close as three meters from the riverbank. Jusoh et al (2012) believe that unless strong and quick measures are made to safeguard the firefly population, the population will continue to decline and finally go extinct. Throughout the research, the abundance of Pteroptyx fluctuated. The highest proportion of abundance (6\%) was found in November and December, while the lowest percentage (2\%) was reported in January and March 2010 (Jusoh \& Ibrahim, 2010). For two months, the firefly colonies for two display trees were missing (January and March) This reflects a lack of firefly colonies in the Dua Ulu and Dua Ilir rivers, where the species and nipah palms were completely absent. Along the Rembau River, the fireflies utilized various plant species as display trees: Sonneratia caseolaris, Rhizophora apiculata, Hibiscus tiliaceus, and Ficus sp. Sixty-five percent of the 87 Pteroptyx colonies were detected on S. caseolaris trees, compared to four to ten colonies on other species of trees (Figure 6). 


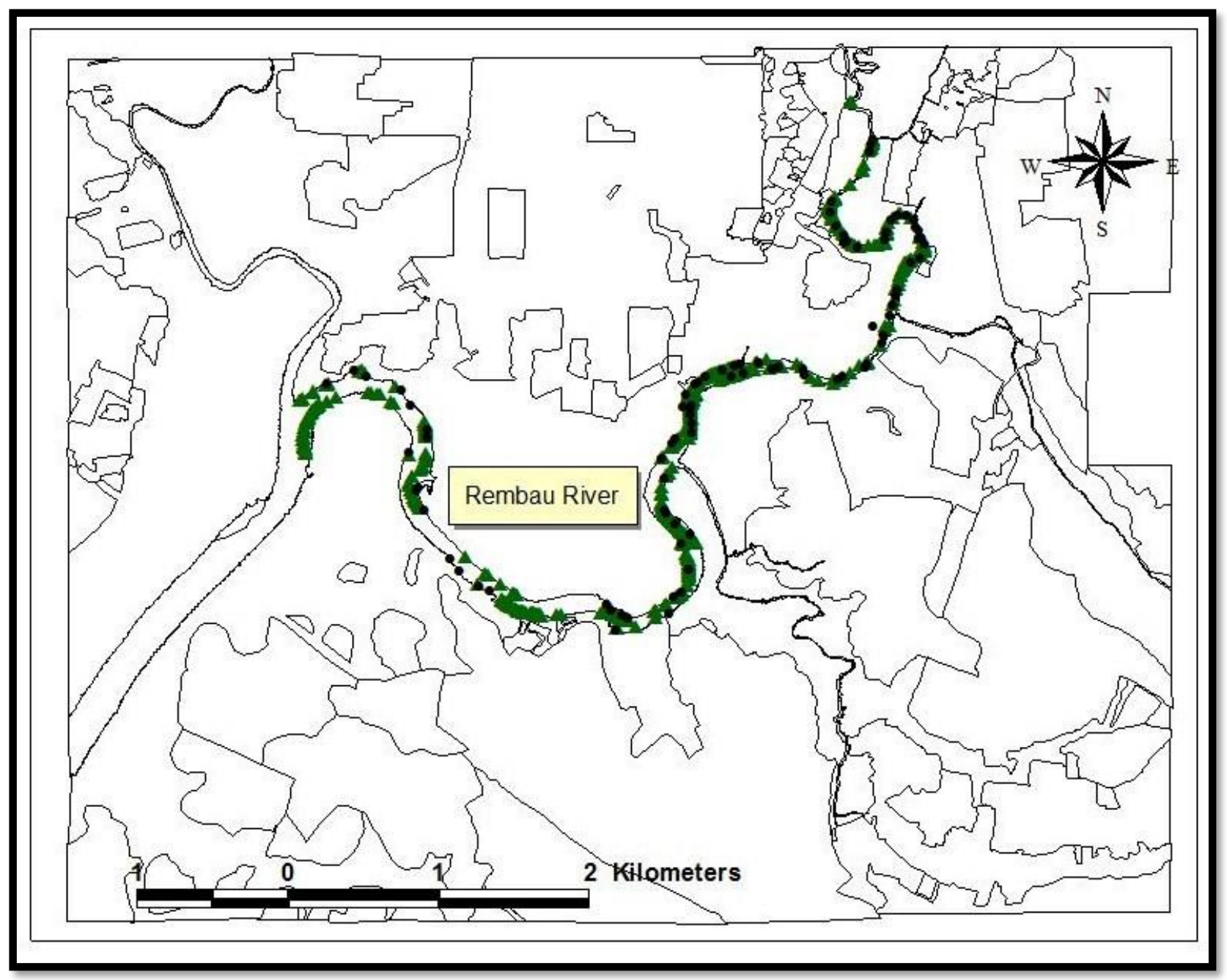

Figure 6. A map depicting the spread of Pteroptyx colonies (black dots) and S. caseolaris trees (green triangle) along the Rembau river (Jusoh \& Ibrahim, 2010)

Environmental parameters such as land use, water quality, rainfall, temperature, humidity also being considered in enhancing the distribution of firefly. A large and virtually continuous stretch of Berembang trees where aggregations of fireflies could be spotted was chosen for observation. Between the riverbanks of Kampung Pengkalan Ladang (Downstream) and Kampung Telok Siam (Upstream) are nine monitoring stations (Figure 7). The adult firefly population along the Selangor River in Kuala Selangor was high in the middle of 2006 and 2007, but low towards the end of 2007. 


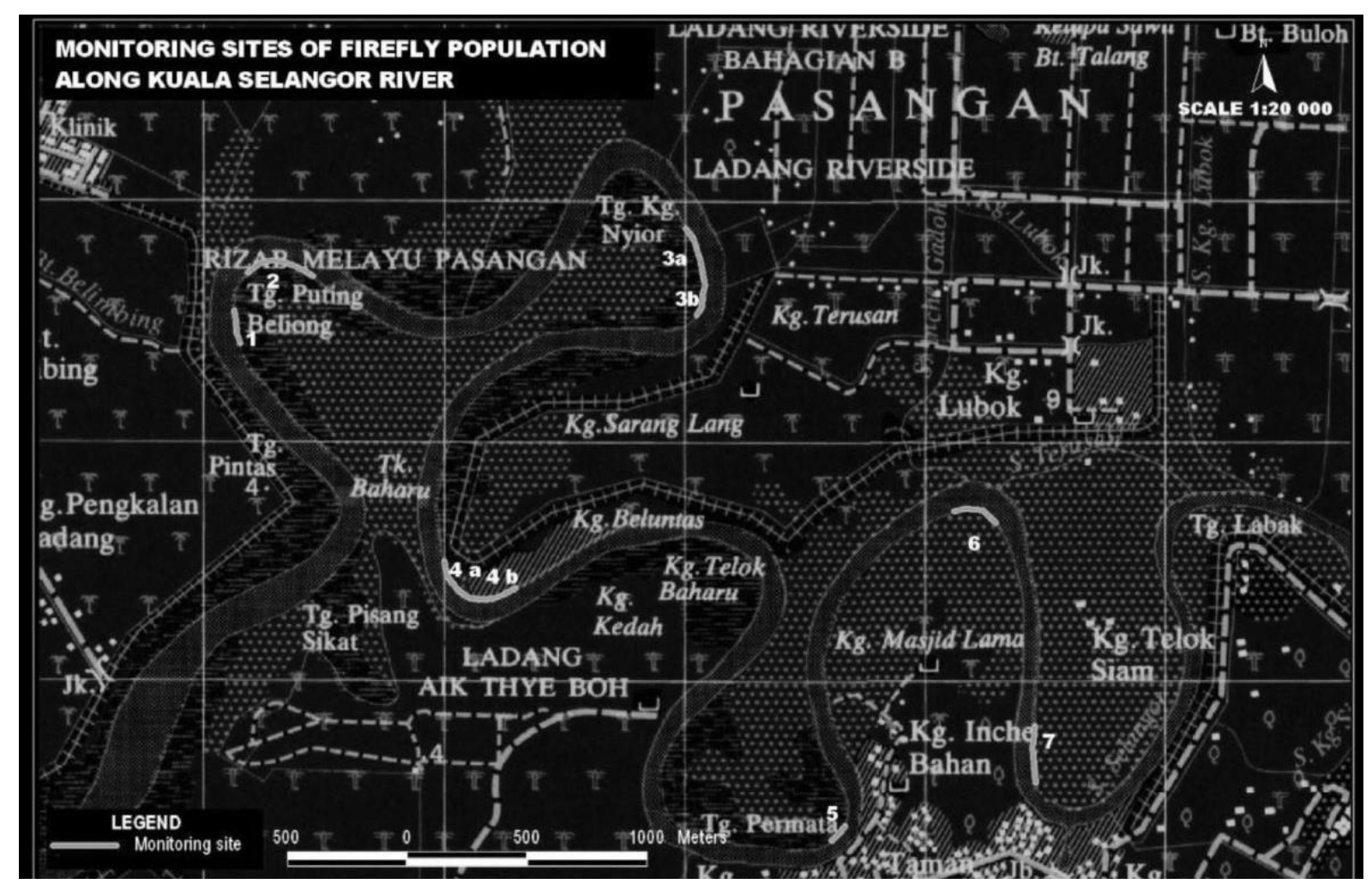

Figure 7. Monitoring Firefly Population along Kuala Selangor River (Nada et al., 2012)

Pteroptyx tener is the most common firefly species found in 40 sample locations in Sungai Bernam, Kuala Selangor (Figure 8), with a male-to-female ratio of 3:1. Between the full moon and the new moon, there was no discernible variation in firefly abundance (PCE) phases. The firefly colonies were mostly found on Berembang and Ficus sp. trees (Sonneratia caseolaris). The PCE value of the firefly was influenced by different locations (right and left banks). Both the right and left river banks had extremely weak and negligible relationships between the key abiotic variables (temperature, relative humidity, wind speed, water salinity, total dissolved solids, and conductivity) and firefly PCE. Although this area has the potential to become a new firefly eco-tourism attraction in the near future, a specific conservation programme is needed to preserve the Bernam river's firefly habitat. For the long-term survival of the firefly colonies, natural riparian vegetation along the Bernam River should be protected and nurtured. 


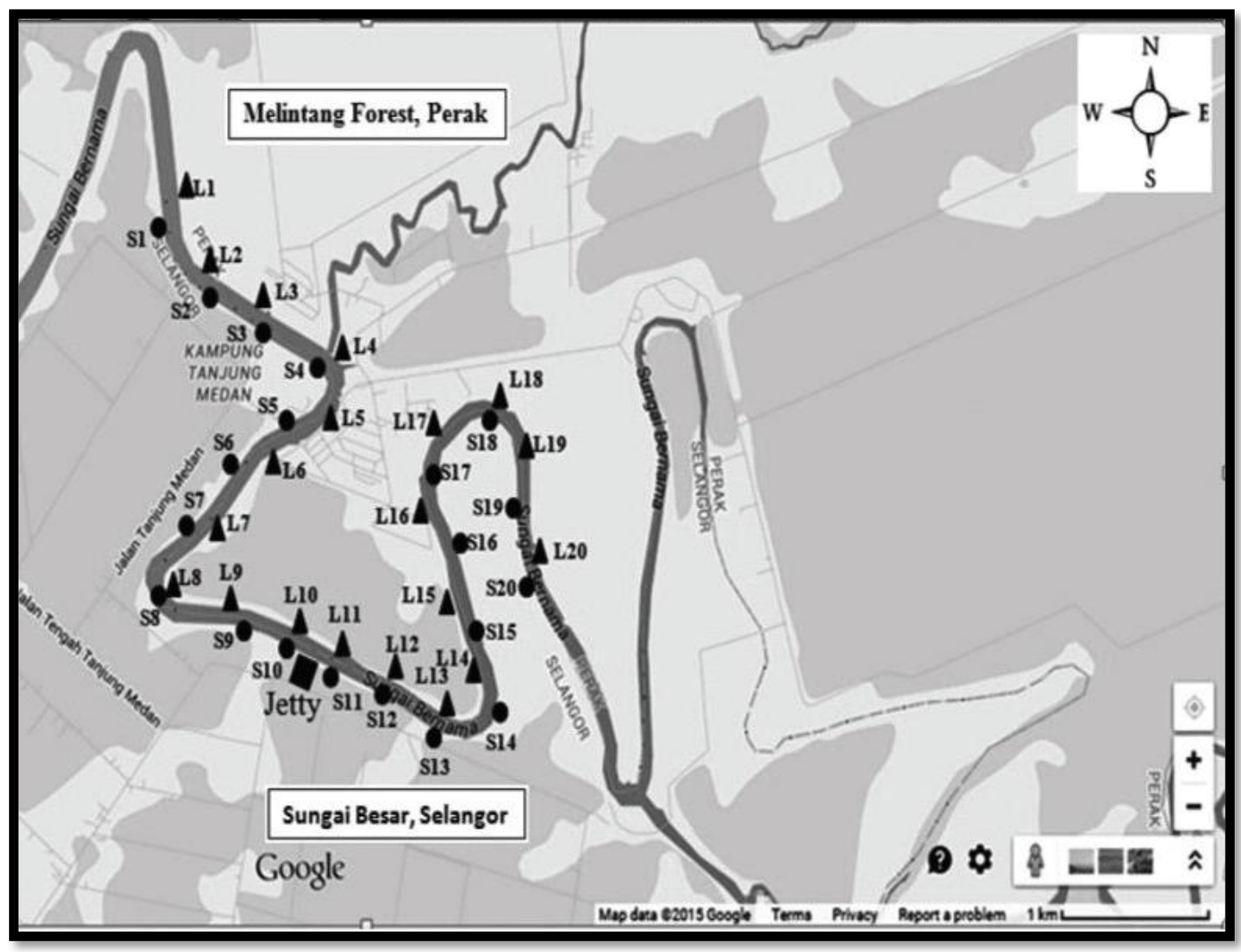

Figure 8. Distribution of Fireflies along Sungai Bernam (Shahara et al., 2017)

\section{Conclusion and Recommendations}

Since fireflies do not mate on the wings, trees are used for mating as a congregational site. Five criteria exist for a tree to be designated as a display tree. As it makes it possible for fireflies to communicate, the display tree must be located near the edge of the river. It must also be close to and in healthy condition to the larval prey food plant. Most of the natural vegetation has been destroyed along the river banks of Sungai Selangor. Fireflies are attracted to Berembang trees and seem to be the most dominant species of tree. More structured conservation and replanting programs will, suggest, researchers, ensure the sustainability of fireflies in this particular environment for sustainability of ecotourism. Athirah (2019) have successfully developed a list of insect taxa in the Peninsular Malaysia Riparian Zones. To compare with actual prospects, the list will result in an enhanced baseline (Abdullah et al., 2019). As it holds the key to the maintenance of the riparian ecosystem as a whole, a conservation effort is much needed, particularly for the vegetation community. According to (Jeperi et al, 2020), a blueprint specifically for firefly conservation should be developed to help focus preservation in the places with the highest need to slow the rate of firefly habitat loss due to development. Beaufort should be promoted as an international destination through comprehensive advertisement, master plan and worldwide link. The local could be trained a citizen scientist to make sure the firefly habitats remain untouched for a long run. The prevalence of congregating firefly populations can be strategically used for tourism purposes. Local communities will benefit directly as a result of this. Fireflies might be regarded an umbrella species that can be utilized to preserve the entire mangrove environment because of their role in tourism. With the assistance of GIS in locating the sampling sites, it is able to map the location of congregating fireflies to conserve and preserve their habitats as well as to attract more ecotourism activities. 


\section{Acknowledgement}

This research was financed by the Ministry of Higher Education of Malaysia under the Fundamental Research Grant Scheme (FRGS) 203.PHUMANITI.6711853.

\section{Corresponding Author}

Dr. Azimah Abd Rahman from Geolnformatic Unit, Geography Section, School of Humanities, Universiti Sains Malaysia, 11800 USM, Pulau Pinang, Malaysia.

Email: azimahrahman@usm.my

\section{References}

Abdullah, N. A., Radzi, S. N. F., Asri, L.N., Idris, N. S., Husin, S., Sulaiman, A., \& Hazmi, I. R. (2019). Insect community in riparian zones of Sungai Sepetang, Sungai Rembau and Sungai Chukai of Peninsular Malaysia. Biodiversity Data Journal, 7, n.p. https://doi.org/10.3897/BDJ.7.e35679

Abdullah, N. A., Asri, L. N., Radzi, S. N. F., Musbah, M., Hazmi, I. R., \& Sulaiman, N. (2021). Abiotic factors influencing diversity and abundance of congregating fireflies (Coleoptera: Lampyridae) in Miri, Sarawak, Malaysia. Oriental Insects, 55(2), 149-164. https://doi.org/10.1080/00305316.2020.1757529

Dawood, M. M., \& Saikim, F. H. (2016). Studies on Congregating Fireflies (Coleoptera; Lampyridae; Pteroptyx sp.) in Sabah, Malaysia: A Review. Journal of Tropical Biology \& Conservation (JTBC), 13(April), 13-25.

Jusoff, K., \& Taha, D. H. D. bin H. (2009). Journal of sustainable development JSD. Journal of Sustainable Development, 1(1), 88. Retrieved from http://www.ccsenet.org/journal/index.php/jsd/article/view/1475/1416

Jusoh et al. (2011). Zonation of firefly species and their display trees along Kerteh River, Terengganu. Serangga, 16(2), 59-66.

Jusoh, W. F. A., \& Hashim, N. R. (2012). The effect of habitat modification on firefly populations at the Rembau-Linggi estuary, Peninsular Malaysia Systematic studies of Fireflies in the Luciolinae View project Fireflies in mangrove forests: retrace the past from present View project.Lampyrid,(January2012).Retrievedfrom: https://www.researchgate.net/publication/258331325

Mckenna, D. D., \& Farrell, B. D. (2015). Beetles ( Coleoptera ). The Timetree of Life, (October 2009), 279-289.

Nada, B., Kirton, L. G., Norma-Rashid, Y., Cheng, S., Shahlinney, L., \& Phon, C. K. (2012). Monitoring the fireflies of the Selangor River. Mangrove and Coastal Environment of Selangor, Malaysia, (June 2017), 153-162.

Saib, S., Dawood, M. M., \& Saikim, F. H. B. (2016). Evaluation of Tourists Satisfaction Towards Firefly Industry in Sabah Using Importance-performance Analysis Model. Transactions on Science and Technology, 3, 93-100.

Shahara, A., Rosli, M. N. A., Abdullah, M., \& Sulaiman, N. (2017). Assessment of firefly abundance at a new ecotourism site of the bernam river, Selangor, peninsular Malaysia. Serangga, 22(2), 33-46.

Wan, F. A., Jusoh, \& Ibrahim, Z. Z. (2010). Distribution and Abundance of Pteroptyx Fireflies in Rembau-Linggi Estuary, Peninsular Malaysia. EnvironmentAsia, (3), 56-60. https://doi.org/10.14456/ea.2010.40 
Hagen, O., Santos, R. M., Schlindwein, M. N., \& Viviani, V. R. (2015). Artificial Night Lighting Reduces Firefly (Coleoptera: Lampyridae) Occurrence in Sorocaba, Brazil. Advances in in Entomology,3, 24-32. Retrieved from: http://dx.doi.org/10.4236/ae.2015.31004.

Khoo, V., Badruddin, N., \& Kirton, L. (2008). Conservation of the Selangor River Population of pteroptyx tener in Malaysia: results of seven years of monitoring. Firefly Simposium.

Forest Research Institute of Malaysia. 1-27. 